GRICZ ISTVÁN

Kultúra és robbanás

Dan Sperber: A kultúra magyarázata. Naturalista megközelítés

$\mathbf{M}$

Á

C

I

Ó

S

$\mathbf{T}$

Á

$\mathbf{R}$

S

A

D

Így hivatkozzon erre a cikkre:

Gricz István. „Kultúra és robbanás”.

Információs Társadalom II, 2. szám (2002): 102-104.

- https://dx.doi.org/10.22503/inftars.II.2002.2.8

A folyóiratban közölt müvek

a Creative Commons Nevezd meg! - Ne add el! - Így add tovább! 4.0

Nemzetközi Licenc feltételeinek megfelelöen használhatók. 


\title{
Kultúra és robbanás
}

\author{
Jurij M. Lotman: Kultura i vzriv
}

A Kultúra és robbanás címú munka Jurij Lotman élete utolsó éveinek gyümölcse, mintegy összegzése annak a több évtizedet felölelő életmúnek, mely az 1900-as évek több mint fél évszázados időszakában született. Lotman könyvében olyan sokrétű kulturális modellt vázol fel, amely a tudomány számos területe mellett a mindennapok tapasztalataiból meríti építôelemeit. A szerzô olvasmányos formában osztja meg eszmefuttatásait, a témák változatossága és a megközelítések sokfélesége pedig érdekes olvasmánnyá teszi írását. A kötet eredeti kiadása 1992-ben, Lotman halála elốtt egy évvel látott napvilágot.

Jurij Mihajlovics Lotman 1922-ben született Szentpéterváron, felsőfokú tanulmányait is itt végezte az akkor már „leningrádinak” nevezett egyetemen. Az író a második világháború után (a tüzérségnél szolgált) visszatért filológiai tanulmányaihoz. A diploma megszerzése után, 1950-ben települt át az észtországi Tartuba, megkezdve szemiotikai kutatómunkáját. Lotman és körének munkássága az évek során önálló irányzattá nôtte ki magát, mely az angolszász irodalomban a "tartu-moszkvai szemiotikai iskola" elnevezést kapta. Szintén a tartui egyetemen jelent meg a hatvanas években az a szemiotikai folyóirat, melyet - először orosz, majd 1992-tốl angol nyelven (Sign Systems Studies) is kiadva - ma a tudományág legjelentôsebb kiadványai között tartanak számon.

Kiterjedt érdeklődése, szerteágazó kutatómunkája alapján Lotman egyfajta modern kori polihisztornak is tekinthetô. A múlt század derekától kezdve élete utolsó éveiig a tudomány számos területén megfordult: foglalkozott orosz irodalommal és történelemmel, kultúraelmélettel, az akkoriban kialakuló robotika tudományával, illetve szemiotikával. Nyomtatásban megjelent múveinek - tanulmányainak, esszéinek, köteteinek - száma eléri a nyolcszázat. Munkásságát sokan Asimovéhoz hasonlítják, persze nem szabad megfeledkezni a két, nem mindennapi életmú jellegének különbségéról.

A Kultúra és robbanás Lotman életének számos különböző történelmi korszakokban szerzett, a tudomány különbözô területeirôl merített tapasztalatait foglalja össze egy szubjektív rendszerben. A kötet teljes egésze Lotman mûveltségének sokszínúségét tükrözi. Elméleteit az orosz történelemből vett példákkal, idézetekkel támasztja alá: IV. Iván korától kezdve az 1980-as évek - akkor még - „szovjet” valóság pillanatképekig.

Lotman alaptétele elsô látásra meglehetôsen banálisnak tûnik: „a szöveg a kultúra egyszerúsített modellje”. A feltevés szerint a szöveg maga nem csupán egy filológiai jelenség, hanem az a komplex, és az értelmező féllel állandó interakcióban levô identitás, mely végsố soron a jelentést hordozza. Lotman tehát megpróbálja a szöveget a jeltan eszközeivel, illetve módszereivel vizsgálni (szemiotikai szövegtan). A Kul- 
túra és robbanás idézetei között ugyanúgy szerepel apró történet a Háború és békéből, filozófiai eszmefuttatás Rousseau-tól és részlet Tatjana leveléből, mint Falstaff egy dialógusa a IV. Henrikből vagy a „szocialista átmenet” jellegzetességeinek taglalása. Alaptételébôl adódóan Lotman a górcsô alá vett „textusokat” soha nem pusztán szövegtani szempontból vizsgálja, inkább egy olyan, több szintû szemiotikai megközelítést alkalmaz, amelynek során kizárólag nem a szövegben foglaltak határozzák meg a pontos jelentést. Más szavakkal Lotman szerint a szövegjelleg egyik ismérve a kifejezettség, tehát a meghatározott jelekkel történố rögzítettség, ez azonban nem zárja ki azt, hogy a rendszeren kívüli elemek ne lennének fontosak. Lényeges, hogy a szövegrôl alkotott lotmani fogalom a lehető legtágabb területre terjed ki. A klasszikus szépirodalmi, múvészi és tudományos múvek mellett napjaink köznapi jelzésrendszerei ugyanúgy beépülnek a kulturális struktúrába mint a film. A filmek szemiotikája a hetvenes években került Lotman érdeklődésének középpontjába. A Kultúra és robbanás egyik fejezete a Chaplin múveiben található jelzések szerepét, illetve idôbeli változásait elemzi. Lotmannál különleges helyet foglalnak el azok a kvázi művészeti alkotások, amelyek megoldandó feladatot hordoznak magukban. Ilyenek például a folklórban nagy mértékben elterjedt találós kérdések, a detektívregények, illetve a film múfaja.

Az alaptétel („a szöveg a kultúra egyszerúsített modellje”) és a többsíkú megközelítés eredményezi Lotman kultúramodelljének megszületését. A modell olyan interakciókon alapul, amelyek a szöveg, a küldő és befogadó, illetve a különböző rendszerek és a külvilág között zajlanak. Lotman a kulturális rendszer változásainak taglalásánál hangsúlyozza, hogy a folyamatot nem elkülönült belső eseményként, de nem is pusztán külsố hatásokra reagáló passzív objektumként kell elképzelni. Lotmannál a két aspektus egyetlen közös tendenciában valósul meg, ily módon lehetetlen őket egymástól elvonatkoztatni, anélkül, hogy ne torzulnának.

Lotman a Kultúra és robbanásban érdekes példákat vonultat fel a kulturális struktúrák és külsố hatások közötti viszony illusztrálására. Kiemeli, hogy bár az ilyen jellegú interakciók előtt napjainkban jóval szélesebb tér nyílik, mint a történelem korábbi szakaszaiban, amikor ugyancsak számos felületen érintkeztek a különböző kultúrák. Lotman szerint ennek egyik legtipikusabb példája az antik hellén-római világ romjaira épülő európai feudalizmus. A feudális rendszer nem csak gyökereiben, belsố szerkezetében hordozta az elmúlt korok jó néhány jegyét. A múlt a külsőségei, a régi-új elnevezések terén is megmutatkozott. Gondoljunk csak a „Szent Római Birodalom” titulusra, vagy arra a széles körben elterjedt gyakorlatra, amikor a „barbár” uralkodók az imperátori cím, vagy a római császárság hatalmi szimbólumainak megszerzésére törekedtek. Lotman itt hívja fel a figyelmet arra, hogy a kultúrába történổ külsô behatolás először mindig szemiotikai síkon, gyakorlatilag a névadás terén történik meg. A külső események csak akkor hatnak igazán a tudatra, akkor válnak emberivé, amikor szemiotikai értelmezést kapnak, tehát bekerülnek a befogadó által használt jelzésrendszerbe, a nyelvbe.

Lotman a kultúra változásait két, egymástól jellegzetességeiben különböző formára osztja: egyik a robbanásszerū, hirtelen változás, másik pedig a folyamatos fejlődés, a dolgok evolúciója. Míg mindkettôt egyformán jelenlevőnek, illetve lényeges tényezốnek tartja, felhívja a figyelmet arra, hogy az utóbbi jóval inkább háttérbe szorult mind a kutatások során, mind pedig a mindennapi szemlélő tudatában. Lotman sze- 
rint ez a gyors, a percepció számára látványosabb, események egyértelmú hatása, ám leszögezi, hogy a lassú, ciklikus folyamatok jelentősége sem törpül el a robbanásszerű változások mellett.

Könyve utolsó negyedében a XX. század második felére látványosan - olykor vasfüggönnyel - elhatárolódott keleti és nyugati társadalmak jellegzetességeit taglalja. Lotman szerint a XX. század végére kialakult „kelet” hagyományosan bináris, kétpólusú beállítottságú, ennek következtében labilisabbnak mondható. Itt kap kiemelt szerepet a „robbanás”, amely a türelmetlen változások féktelen dühével hátrahagyott nyomok nélkül próbálja elsöpörni a múltat, üres űrt hagyva a letűnt hagyományok helyén. A kétpólusú rendszer a meglévố dolgokat annak nevében semmisíti meg, hogy azok jóvátehetetlen bűnöktôl szennyesek. Háttere, illetve hatása azonban nem azonosítható az elsô pillantás után, így radikalizmusával, valamint az „új ég és új föld” azonnali felépítésének ígéretével nagy tömegeket képes magához vonzani.

Ezzel ellentétben a „hárompólusú” nyugat több lábon áll, hiszen a rendszer biztonságosabban felépített, ezért a legmélyebbre hatoló változások, robbanások sem képesek a szociális rétegek egész gazdagságát átfogni. A hagyományok itt is módosulnak ugyan az idôk során, ám itt a változás és az értékôrzés egyaránt megvalósul.

Lotman - aki a múlt század hatvanas évtizedeiben a Szovjetunió elsô, „nyugaton" is elismert tudósai közé tartozott - az 1990-es évek elején egy, közel fél évszázadon át fennálló, rendszer széthullása idején írja ezeket a gondolatokat. A különbözố modelleket a szocialista átalakulás kapcsán is összehasonlítja: eszerint a kétpólusú rendszer a gyakorlatban akarja megvalósítani a sok esetben megvalósíthatatlan ideált, a hárompólusú pedig inkább arra törekszik, hogy ideáljait a valósághoz igazítsa. A szerzổ az önmagát körülvevố valóságból táplálkozó eszmefuttatásokat visszavezeti forrásukhoz: Lotman szerint a kulturális, illetve társadalmi átalakulások terén korunkban kiemelt fontosságot kap a robbanásokra orientált gondolkodásmód háttérbe szorítása és a folyamatos fejlôdést hangsúlyozó tudat erôsítése. Hazájával kapcsolatosan kifejti azt, hogy az orosz tudatban már Nagy Péter óta él az „utolérni és túlszárnyalni Európát” gondolata, mely a XX. század második felének „öt éves tervet négy év alatt” jelszavában is megtalálható. Lotman szerint ez a modell, mely megpróbálja „sürgetni a történelmet" múködésképtelen, a folyamatos fejlődést a robbanás eszközeivel siettetni nem lehet.

A kulturális és társadalmi rendszerek együttes változásainak fejtegetésével Lotman elér múve zárógondolatához, mely gyakorlati síkra vetítve az ezredforduló Európájának egyik nagy feladata: a korábban két részre osztott kontinens változó korszakában elôttünk áll a lehetôség arra, hogy „áttérjünk az összeurópai hárompólusú szisztémára, és lemondjunk arról a régi ideálról, amely szerint le kell rombolnunk a régi világot az alapokig, aztán pedig felépítenünk a romjain az újat. Ennek a lehetőségnek az elszalasztása történelmi katasztrófa lenne".

Jurij M. Lotman (1992): Kultura i vzriv; Gnozisz Kiadó, Moszkva, fordította: Szűcs Teri 